\title{
Acute gastroenteritis associated with Rotavirus A among children less than 5 years of age in Nepal
}

\author{
Sony Shrestha ${ }^{1 *}$ DiD, Ocean Thakali ${ }^{1}$, Sunayana Raya ${ }^{1}$, Laxman Shrestha², Keshab Parajuli ${ }^{1}$ \\ and Jeevan Bahadhur Sherchand ${ }^{1}$
}

\begin{abstract}
Background: Rotavirus gastroenteritis is a major public health problem in Nepal. This study was conducted to obtain information associated with Rotavirus gastroenteritis and to perform genotyping of Rotavirus A.

Methods: Hospital based cross sectional study was conducted from January to December 2017 among children less than 5 years of age attending Kanti Children's Hospital and Tribhuvan University Teaching Hospital. Rotavirus A antigen detection was performed by Enzyme Linked Immunosorbent Assay (ELISA) using ProSpecT Rotavirus Microplate Assay. Rotavirus A positive strains were further confirmed by genotyping using Reverse-Transcription Polymerase Chain Reaction (RT-PCR).

Results: A total of 1074 stool samples were collected, of them 770 were hospitalized, and 304 were nonhospitalized cases. Rotavirus A infection was found in $28 \%$ of children with infection rate higher in hospitalized (34\%) than in non-hospitalized (14\%) children. Rotavirus A detection was higher in male (31\%) than in female (24\%), but this was statistically not significant $(p>0.05)$. Rotavirus A positivity was higher in children of age group 0-23 months, this result was statistically not significant $(p>0.05)$ with higher frequency found in the months of November, December, January, February and March $(p<0.05)$. On the basis of molecular analysis of Rotavirus A genotyping, G12P[6] (46.39\%) was found to be the predominant followed by G1P[8] (35.05\%), G3P[8] (7.21\%) and G1P[6] (5.15\%) while $4.12 \%$ was mixed infection and $1.03 \%$ was partially typed $(p<0.05)$.

Conclusion: Rotavirus A infection occurred throughout the year, but the infection was significantly higher during the month of March. The higher frequency of rotavirus infection was observed among children of age group 0-23 months; however this was not found to be statistically significant. In this study, G12P[6] is predominant genotype observed. The results of genotyping are essential for the introduction of Rotavirus vaccine in Nepal.
\end{abstract}

Keywords: Rotavirus, Genotyping, Gastroenteritis, Nepal

\section{Background}

Acute gastroenteritis (AGE) is an extremely common illness among infants and children worldwide [1]. It is an inflammation of the gastrointestinal tract characterized by diarrhea and symptoms of gastric irritation (e.g nausea, vomiting, and epigastric pain) caused by microbial agents [2,3]. Diarrhea is defined

\footnotetext{
* Correspondence: friendlysony@gmail.com

${ }^{1}$ Department of Clinical Microbiology and Public Health Research Laboratory, Maharajgunj Medical Campus, Institute of Medicine, Tribhuvan University Teaching Hospital, Kathmandu, Nepal

Full list of author information is available at the end of the article
}

by World Health Organization (WHO) as having 3 or more loose or liquid stools per day or as having more stools than in normal for that person [4]. Diarrheal diseases are associated with an estimated 1.3 million deaths annually, with most occurring in resource-limited countries; up to $25 \%$ of deaths in young children living in Africa and south-east Asia are attributable to AGE [5].

Diarrhea can be caused by a wide range of virus, bacteria and parasites. In both developed and developing countries, viruses are the leading cause of acute diarrhea [6]. Among all viral diarrheal agents,

(c) The Author(s). 2019 Open Access This article is distributed under the terms of the Creative Commons Attribution 4.0 International License (http://creativecommons.org/licenses/by/4.0/), which permits unrestricted use, distribution, and 
Rotavirus is a major cause of AGE which results in nearly 200,000 deaths annually in children younger than 5 years $[7,8]$. A systematic review of Rotavirus A gastroenteritis in children less than five years of age from Asia, found Rotavirus A to be associated with approximately 145,000 deaths every year [8]. By the age of five years, nearly every child has been infected at least once and reinfection is mild [9].

Nepal being a developing country, diarrheal diseases are major problem. Precise data on childhood mortality associated with diarrheal diseases in Nepal is not available. But in 2016/17, 1,184,120 cases of Diarrhoea were reported of which $0.44 \%$ suffered from severe dehydration (increased from $0.2 \%$ the previous year). The national incidence of diarrhoea per 1000 under- 5 year olds decreased from $422 / 1000$ in $2015 / 16$ to $400 / 1000$ in fiscal year 2016/17 [10].

Symptoms of Rotavirus A disease often start within 1-3 days of infection with vomiting followed by 4-8 days of profuse diarrhoea. Rotavirus A replicates in the cytoplasm of mature enterocytes lining the tips of intestinal villi, preventing uptake of nutrients and causing severe diarrhea that can be fatal if left untreated. Rotavirus A sheds in high concentration in the stool and spreads by fecal-oral route before two days and after ten days of onset [11].

There are differences in the distribution of Rotavirus $\mathrm{A}$ infections according to age in developing and developed countries. In the former, the highest rates occur during the first year of life. However, in developed countries, peak rates occur in the second year of life. This could emphasize the need of Rotavirus A vaccine being applied earlier in life to children in developing countries [12]. It is generally believed that serotype-specific immunity plays a role in protection against disease, so the epidemiology of circulating genotype of Rotavirus A forms a critical knowledge base for the development and implementation of Rotavirus vaccines [13].

So, this study was conducted to obtain more information about Rotavirus A gastroenteritis which is important for health care workers and policymakers. Such information can be helpful to improve the diagnosis and treatment of infection and also will be useful to provide information for future projection and evaluation of child health diarrheal disease and future vaccine implementation.

\section{Research questions}

- Is there increasing trend in rotavirus gastroenterititis among Children in Nepal?

- Is there any significant relation between AGE and the age, gender and month of sample collection?

\section{Methods}

The study was carried out in Deparment of Clinical Microbiology, Public Health Research Laboratory, Institute of Medicine, Tribhuvan University Teaching Hospital (TUTH), Maharajgunj, Kathmandu. Written informed consent was requested from children's parents/ guardians from all eligible cases. Stool samples were requested from the children under 5 years of age visiting Kanti Children's Hospital and TUTH, Kathmandu, with acute diarrhoea in the period between January to December 2017 and whose parents/guardians provided consent to participate in the study.

\section{Inclusion criteria}

Case-patients were eligible for enrollment in the study if they met the following criteria:

1. All children under 5 years who presented at the study site/hospital for treatment of diarrheal illness with or without intake of medications.

2. Has acute diarrhea with duration of $\leq 14$ days.

3. Admission to the diarrheal treatment unit (IPW) and hospital catchment area.

\section{Exclusion criteria}

Cases were excluded if they met any of the following criteria:

1. Children with diarrhea occurring after hospital admission- that is children admitted with separate diagnosis (non-diarrhea) initially and later developing diarrhea at any time during admission.

2. Children presenting or diagnosed to have chronic or persistent diarrhea (diarrhea that last for more than 2 weeks).

\section{Sample collection, storage and testing}

From each participating child, clinical data were obtained and the stool sample was collected in a sterile container. The collected stool samples were preserved at $-20{ }^{\circ} \mathrm{C}$ until they were analysed. Rotavirus A infection was tested using an antigen detection test by ELISA (ProSpecTM Rotavirus Microplate Assay, Oxoid) according to the instructions of the manufacture. Then the samples were stored at $-80{ }^{\circ} \mathrm{C}$ for genotyping. Subsequently random 100 Rotavirus A antigen positive samples were subjected to genotyping by RT-PCR.

For molecular typing, genomic RNA was extracted using the QIAamp viral RNA mini kit (Qiagen), according to the manufacturer's instructions. VP7 (G) and VP4 (P) genotypes were detected by RT-PCR according to methods described previously [13-15]. 
Table 1 PCR primers and cycling conditions used for VP7 genotyping of Rotavirus A strains

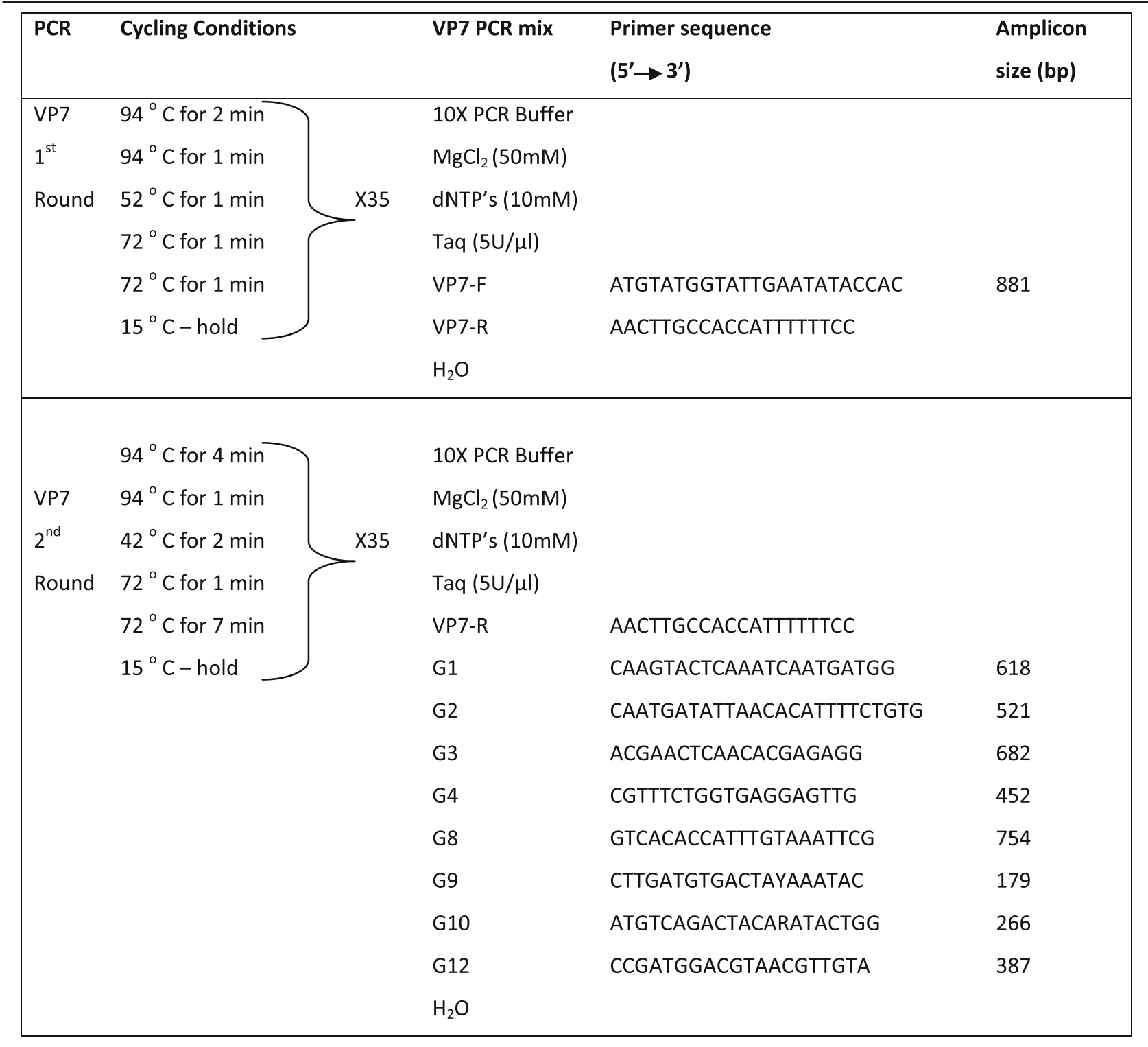

For Rotavirus G genotyping, the VP7 gene was amplified by RT-PCR with VP7/F and VP7/R primers (Table 1). For Rotavirus $\mathrm{P}$ genotyping, the VP4 gene was amplified by RT-PCR with con- 2 and con-3 primers (Table 2).

\section{Data interpretation}

\section{Gel electrophoresis and documentation}

Identification of Rotavirus genotypes were done on the basis of PCR amplicon size by using gel electrophoresis. Preparation of $2 \%$ agarose gel was done by weighing $2 \mathrm{~g}$ of agarose in $100 \mathrm{ml}$ of $1 \mathrm{X}$ Tris-boric acid EDTA (TBE) and was stained with ethidium bromide $(0.5 \mathrm{mg} / \mathrm{ml})$. The gel was poured onto set electrophoresis tray and PCR amplicons were resolved at $100 \mathrm{~V}$ for $2 \mathrm{~h}$. Images were photographed under UV light using a gel documentation system.

\section{Validity and reliability}

For ELISA test, inactivated bovine Rotavirus mixed with buffer was used as positive control and tris buffered saline solution as negative control. For genotyping PCR assays we used genotype G1P[8] as a positive control.

\section{Analysis}

Data entry was done in Excel and analyzed using SPSS (Version 16). $P$ values were calculated using Chi- square test and value $<0.05$ were considered statistically significant. 
Table 2 PCR primers and cycling conditions used for VP4 genotyping of Rotavirus A strains

\begin{tabular}{|c|c|c|c|c|}
\hline PCR & Cycling Conditions & VP7 PCR mix & $\begin{array}{l}\text { Primer sequence } \\
\left(5^{\prime} \rightarrow 3^{\prime}\right)\end{array}$ & $\begin{array}{l}\text { Amplicon size } \\
\text { (bp) }\end{array}$ \\
\hline $\begin{array}{l}\text { VP4 } \\
1^{\text {st }} \\
\text { Round }\end{array}$ & $\left.\begin{array}{l}94^{\circ} \mathrm{C} \text { for } 2 \text { min } \\
94^{\circ} \mathrm{C} \text { for } 1 \text { min } \\
50^{\circ} \mathrm{C} \text { for } 1 \text { min } \\
72^{\circ} \mathrm{C} \text { for } 1 \text { min } \\
72^{\circ} \mathrm{C} \text { for } 7 \text { min } \\
15^{\circ} \mathrm{C}-\text { hold }\end{array}\right\}$ & $\begin{array}{l}\text { 10X PCR Buffer } \\
\mathrm{MgCl}_{2}(50 \mathrm{mM}) \\
\text { dNTP's }(10 \mathrm{mM}) \\
\text { Taq }(5 \mathrm{U} / \mu \mathrm{l}) \\
\text { Con-2 } \\
\text { Con-3 } \\
\text { DEPC } \mathrm{H}_{2} \mathrm{O}\end{array}$ & $\begin{array}{l}\text { ATTTCGGACCATTTATAACC } \\
\text { TGGCTTCGCCATTTTATAGACA }\end{array}$ & 876 \\
\hline $\begin{array}{l}\text { VP4 } \\
2^{\text {nd }} \\
\text { Round }\end{array}$ & $\left.\begin{array}{l}94^{\circ} \mathrm{C} \text { for } 2 \text { min } \\
94^{\circ} \mathrm{C} \text { for } 1 \text { min } \\
45^{\circ} \mathrm{C} \text { for } 2 \text { min } \\
72^{\circ} \mathrm{C} \text { for } 1 \text { min } \\
72^{\circ} \mathrm{C} \text { for } 7 \text { min } \\
15^{\circ} \mathrm{C}-\text { hold }\end{array}\right\}$ X35 & $\begin{array}{l}\text { 10X PCR Buffer } \\
\mathrm{MgCl}_{2}(50 \mathrm{mM}) \\
\text { dNTP's }(10 \mathrm{mM}) \\
\text { Taq }(5 \mathrm{U} / \mu \mathrm{l}) \\
\text { Con-3 } \\
\text { P4 } \\
\text { P6 } \\
\text { P8 } \\
\text { P9 } \\
\text { P10 } \\
\text { P11 } \\
\text { DEPC } \mathrm{H}_{2} \mathrm{O}\end{array}$ & $\begin{array}{l}\text { TGGCTTCGCCATTTTATAGACA } \\
\text { CTATTGTTAGAGGTTAGAGTC } \\
\text { TGTTGATTAGTTGGATTCAA } \\
\text { TCTACTGGRTTRACNTGC } \\
\text { TGAGACATGCAATTGGAC } \\
\text { ATCATAGTTAGTAGTCGG } \\
\text { GTAAACATCCAGAATGTG }\end{array}$ & $\begin{array}{l}876 \\
483 \\
267 \\
345 \\
391 \\
583 \\
312\end{array}$ \\
\hline
\end{tabular}

\section{Results}

A total of 1074 stool samples examined for Rotavirus A using ELISA, 302/1074 (28\%) samples were found Rotavirus $A$ positive with infection rate being higher in hospitalized (i.e. all hospital admitted cases) 261/770 (34\%) than in non-hospitalized (cases seen in OPD) 41/304 (14\%) children, this observation was statistically significant $(p<0.05)$. Rotavirus A detection was higher in male
$(197 / 642=31 \%)$ than in female $(105 / 432=28 \%) \quad(p>$ $0.05)$.

Distribution of rotavirus infection on the basis of age Though Rotavirus A infection was seen highest in children of age group $0-11$ months (30\%) followed by $12-$ 23 , this result is statistically not significant $(27 \%)(p>$ 0.05 ) as shown in Table 3.

Table 3 Age distribution of Rotavirus A infection

\begin{tabular}{lllllll}
\hline Age group (month) & $\begin{array}{l}\text { Total number } \\
\text { of cases }\end{array}$ & $\begin{array}{l}\text { Total Rotavirus } \\
\text { positive cases (\%) }\end{array}$ & $\begin{array}{l}\text { Total hospitalized } \\
\text { cases }\end{array}$ & $\begin{array}{l}\text { Rotavirus positive among } \\
\text { hospitalized cases (\%) }\end{array}$ & $\begin{array}{l}\text { Total } \\
\text { non- } \\
\text { hospitalized cases }\end{array}$ & $\begin{array}{l}\text { Rotavirus positive } \\
\text { among } \\
\text { Non-hospitalized cases (\%) }\end{array}$ \\
\hline $0-11$ & 646 & $196(30)$ & 455 & $162(36)$ & 191 & $34(18)$ \\
$12-23$ & 287 & $77(27)$ & 209 & $70(34)$ & 35 & $7(9)$ \\
$24-59$ & 141 & $29(21)$ & 106 & $29(27)$ & 304 & 0 \\
Total & 1074 & $302(28)$ & 770 & $261(34)$ & $41(14)$ \\
\hline
\end{tabular}




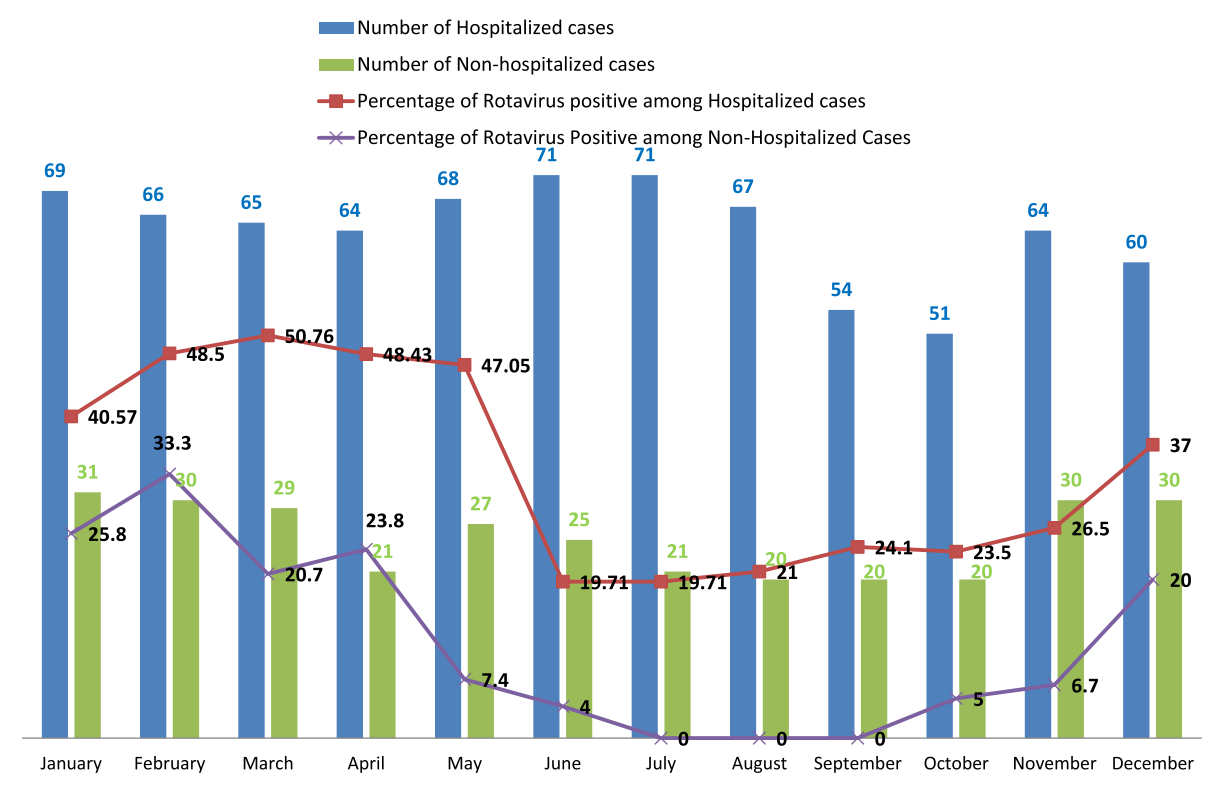

Fig. 1 Monthly occurrence of Rotavirus diarrhoea

Monthly occurrence of rotavirus a diarrhea

In this study, isolation of Rotavirus A was found to be highest in the month of March followed by February, this finding was statistically significant $(p<0.05)$ as shown in Fig. 1

\section{Clinical symptoms and rotavirus detection among diarrheal children}

The most common clinical symptoms among the children enrolled were dehydration (some $92 \%$ and severe $8 \%)$, fever (25\%), vomiting (36\%), nausea (43\%) and abdominal pain (100\%). Rotavirus A infection among cases with some dehydration is $26 \%$ and severe dehydration $47 \%$, whereas infection rate in children with fever, vomiting, nausea and abdominal pain is 27,40 , 29 and $28 \%$ respectively.

\section{Genotypic distribution of rotavirus a}

On the basis of genotyping results of Rotavirus A, G12P[6] (46.39\%) was found to be the predominant genotype followed by G1P[8] (35.05\%), G3P[8] (7.21\%) and G1P[6] (5.15\%) while 1.03\% was partially typed, this

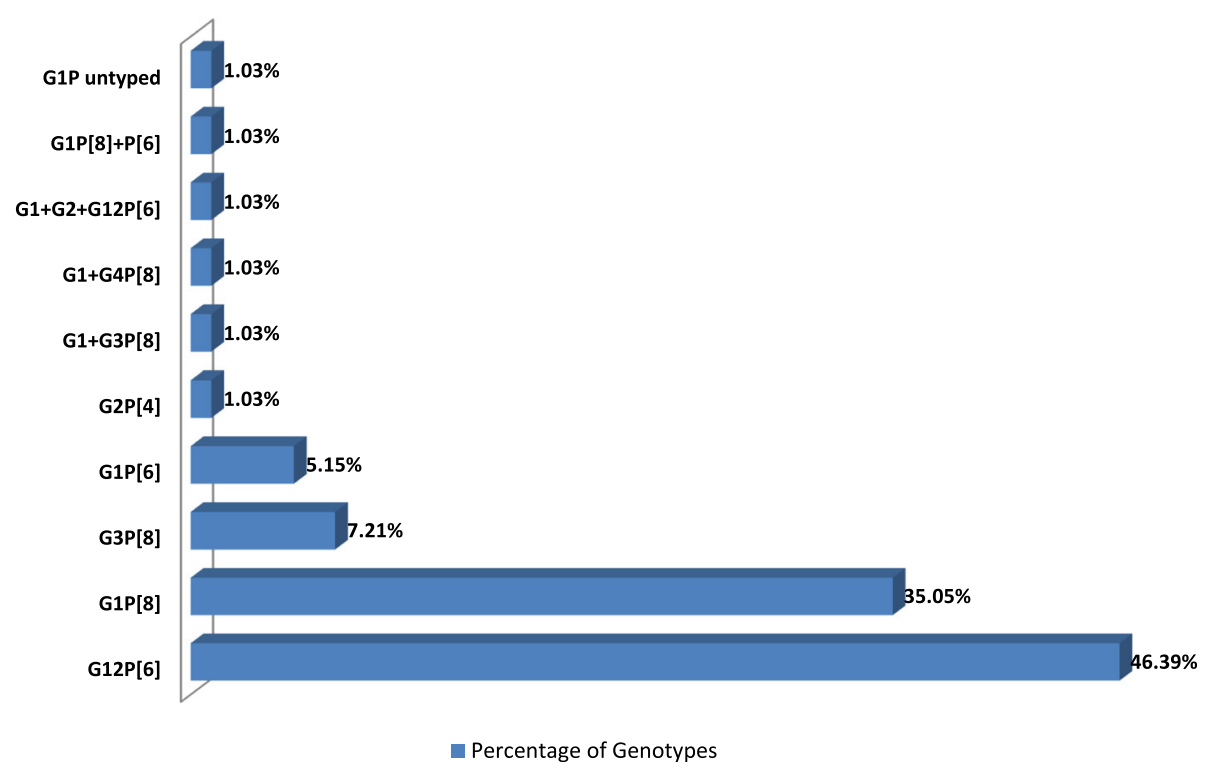

Fig. 2 Genotypic distribution of Rotavirus A 


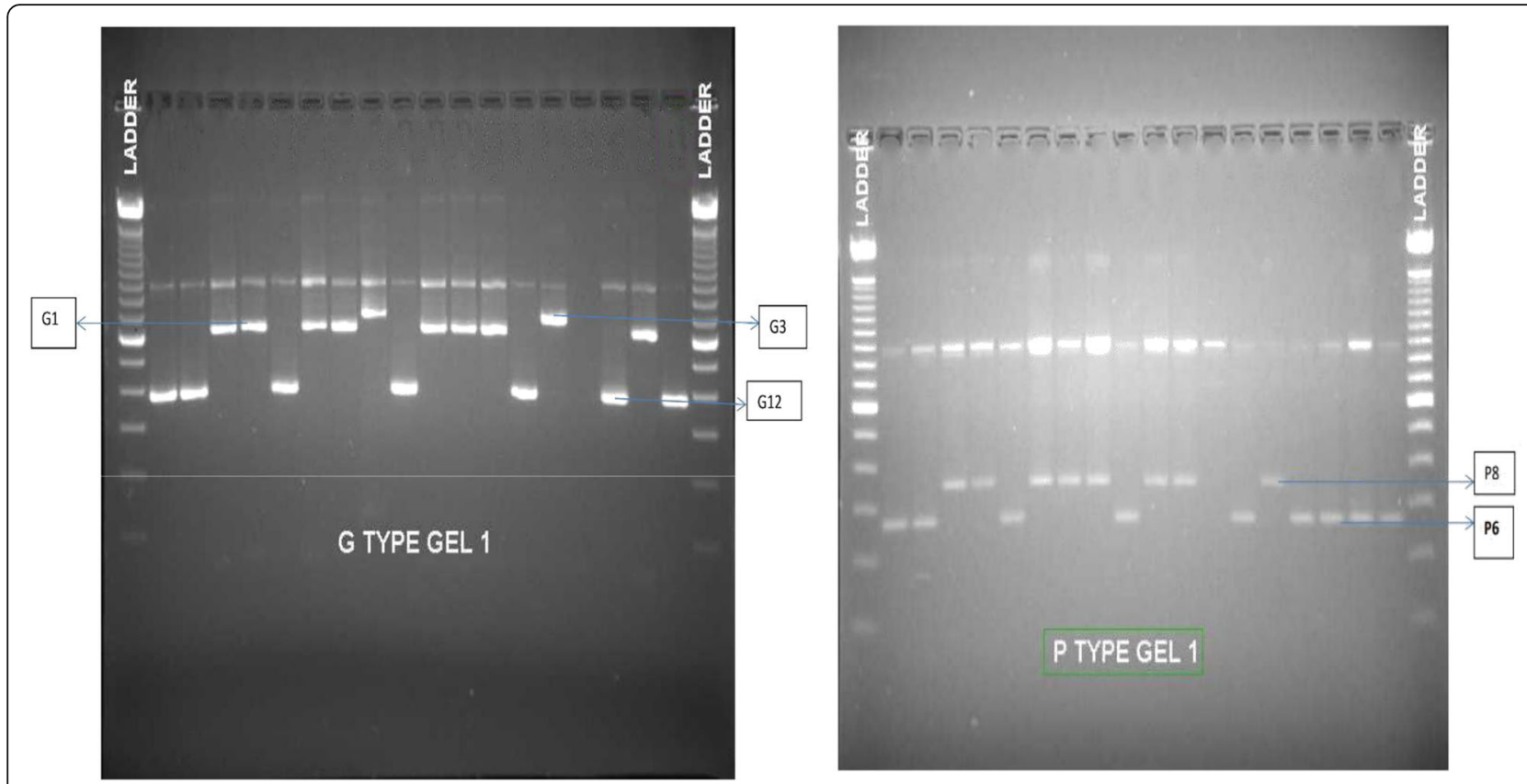

Fig. 3 Gel run of G-type and P-type PCR analysis

finding was statistically significant $(P<0.05)$ as elucidate in Fig. 2.

The genotype was determined on the basis of gel electrophoresis of the product which differed according to the base pairs as shown in Fig. 3.

\section{Discussion}

The present study revealed that Rotavirus A infection was $28 \%$. This study is similar to other studies conducted by Sherchand et al. (35.4\%) [16], Dhital et al. (22.9\%) [17], Ansari et al. (25.9\%) [18], Pun et al. (23.5\%) [19], Saeed et al. (22\%) [20] and Akran et al. (28.9\%) [21] while Reither et al. (55\%) [22] reported slightly higher positivity rate. Although, improvements in nutrition hygiene, increased awareness among caretakers and the use of oral rehydration therapy contributed to declining the incidence of diarrheal diseases over the past years in Nepal, this result revealed that Rotavirus A infection remained high among diarrheal children [19].

In this study, the infection rate of Rotavirus $\mathrm{A}$ is higher in hospitalized 261 (34\%) than in non-hospitalized 41 $(14 \%)$ children, this observation was statically significant $(p<0.05)$. This is in accordance with other studies [13, 14, $16,23,24]$. Gender distribution of diarrheal cases showed higher prevalence in male (30.69\%) than in female (24.31\%). Although some other studies also observed a higher prevalence of diarrhea among male $[18,25]$, but prevalence of Rotavirus infection among gender was not found to be statically significant in this study. Prevalence of Rotavirus A among younger age group was statistically not significant. This may be due to sample collection bias. In the case of younger ones, parents are more concern and hence, they visit the hospital immediately whereas in elder ones, they don't visit the hospital unless it become severe. Our result is closer to the results of Sherchand et al. [23], Ahmed et al. [26] and Johargy et al. [27] . Thus, vaccination at an early age can be beneficial to prevent majority cases of diseases [17].

Rotavirus A infection occurred all year round but peaked during the month of March followed by February that is during the dry weather, this result was statistically significant $(p<0.05)$. This finding is in accordance with other studies reported by Sherchand et al. [23], Pun et al. [19] and Dhital et al. [17].

In our study, abdominal pain was the most common clinical symptom among 1074 children with acute diarrhea. Whereas, the degree of dehydration among enrolled cases was more likely to be some to severe.

On the basis of molecular analysis of Rotavirus A, G12P[6] (46.39\%) was found to be the most common genotype followed by G1P[8] (35.05\%), G3P [8] (7.21\%) and G1P[6] (5.15\%) while $4.12 \%$ was mixed infection and $1.03 \%$ was partially type. The predominance of G12P[6] is in accordance with other studies of Sherchand et al. (45.7\% in 2009) and (28.47\% in 2010) [23], Ansari et al. (46.4\% in 2011), Sherchand et al. (48\% in 2012) [16]. Approximately $90 \%$ of all human rotaviral diarrhea is due to 5 G-P combinations (G1P[8], G2P [4], G3P[8], G4P[8]) and G9P[8]) globally [17]. G12 is also becoming important in human diarrheal disease as it is 
recognized as an emerging genotype [23, 28]. It has been reported that unusual $\mathrm{G}$ and $\mathrm{P}$ combinations constitute more than $14 \%$ of reported Rotavirus A isolates from Asia, 27\% from Africa, 11\% from South America, 5\% from North America, 1.4\% from Europe, and 0.1\% from Australia [29].

After Rotavirus A vaccine introduction there is fluctuation in the genotype distribution annually and geographically [30]. In Nepal, still Rotavirus A vaccination has not been incorporated in the national immunization schedule, but due to high burden of Rotavirus A infection vaccination is necessary. After execution of vaccination program decrease in the burden of diarrhea can be expected from the experience of countries like USA, Finland, Belgium, Brazil, Venezuela and Mexico where Rotavirus A vaccination has been adopted [17].

\section{Limitation of the study}

This study was limited only to patients of acute diarrhea visiting hospital in Kathmandu and time framework for the study was only 1 year.

\section{Conclusion}

The present study indicates that Rotavirus A was the cause of $28 \%$ of the diarrheal cases studied and that Rotavirus is major problem in children under 5 years of age. Molecular analysis revealed that G12P[6] were the major genotype followed by G1P[8], G3P[8] and G1P[6] causing Rotavirus diarrhea. High prevalence of group A Rotavirus infection in children with diarrhoea and also the determination of circulating Rotavirus A genotypes provides useful data for formulating new and more effective vaccines, especially for infants. As these findings do not represent the complete scenario nationwide, further analysis is necessary to determine the prevalence of rotaviral infection in Nepal.

\section{Additional file}

Additional file 1: Rotavirus dataset, 2017(the data generated during this study, includes the data generated like month of hospital visit, number of diarrhea, vomiting, ELISA results, genotyping results in excel sheet.) (XLSX $157 \mathrm{~kb})$

\section{Abbreviations \\ AGE: Acute gastroenteritis; ELISA: Enzyme Linked Immunosorbent Assay; IPW: In-patient ward; RT-PCR: Reverse-Transcription Polymerase Chain Reaction; TBE: Tris-boric acid EDTA; TUTH: Tribhuvan University Teaching Hospital; WHO: World Health Organization}

\section{Acknowledgements}

We would like to acknowledge Kanti-children's Hospital, Child Health Division and Department of Microbiology, Institute of Medicine, Tribhuvan University.

\section{Funding}

Our study received grant from University Grant Commission (UGC),

Bhakatpur, Nepal. Funder has no any role in our study.

\section{Availability of data and materials}

The dataset generated during the study are available within the Additional file 1.

\section{Authors' contributions}

First Author: SS is primary and corresponding author, who designed the study methodology, collected data and sample, performed laboratory investigation and prepared the article for submission. Second Authors: OT and SR helped in data collection and statistical analysis. JBS, KP and LS are faculties of the Department who are my supervisors and they helped for literature review, design the study, prepare the laboratory protocols and analyzing the impact of the study. All authors have read and approved the manuscript.

Ethics approval and consent to participate

Ethical approval was obtained from the Institutional Review Board (IRB) Institute of Medicine, Tribhuvan University Teaching Hospital, Kathmandu, Nepal. Written informed consent was obtained from the children's parents or guardians before enrolment.

\section{Consent for publication}

Not Applicable.

\section{Competing interests}

The authors declare that they have no competing interests.

\section{Publisher's Note}

Springer Nature remains neutral with regard to jurisdictional claims in published maps and institutional affiliations.

\section{Author details}

${ }^{1}$ Department of Clinical Microbiology and Public Health Research Laboratory, Maharajgunj Medical Campus, Institute of Medicine, Tribhuvan University Teaching Hospital, Kathmandu, Nepal. ${ }^{2}$ Department of Child Health, Institute of Medicine, Tribhuvan University Teaching Hospital, Kathmandu, Nepal.

Received: 17 December 2018 Accepted: 15 May 2019

Published online: 22 May 2019

\section{References}

1. Granado-Villar D, Cunill-De Sautu B, Granados A. Acute gastroenteritis. Pediatr Rev. 2012;33(11):487-95.

2. Elliott EJ. Acute gastroenteritis in children. BMJ: British Medical Journal. 2007; 334(7583):35.

3. Howidi M, Al Kaabi N, El Khoury AC, Brandtmüller A, Nagy L, Richer E, Haddadin W, Miqdady MS. Burden of acute gastroenteritis among children younger than 5 years of age-a survey among parents in the United Arab Emirates. BMC pediatrics. 2012;12, 74.

4. Organization WH: Diarrhoea: why children are still dying and what can be done. 2009.

5. Mokomane M, Kasvosve I, Ed M, Pernica JM, Goldfarb DM. The global problem of childhood diarrhoeal diseases: emerging strategies in prevention and management. Therapeutic advances in infectious disease. 2018;5(1):29-43.

6. Elhag WI, Saeed HA, El Fadhil EO, Ali AS. Prevalence of rotavirus and adenovirus associated with diarrhea among displaced communities in Khartoum, Sudan. BMC Infect Dis. 2013;13(1):209.

7. Tate JE, Burton AH, Boschi-Pinto C, Parashar UD, Network WHOCGRS, Agocs M, Serhan F, de Oliveira L, Mwenda JM, Mihigo R. Global, regional, and national estimates of rotavirus mortality in children< 5 years of age, 2000 2013. Clinical Infectious Diseases. 2016;62(suppl_2):S96-S105.

8. Giri S, Hemavathy RP, Arumugam R, Sherchand JB, Thu HM, Galagoda G, Myat TW, Abeysinghe N, Gunasekara M, Janakan N. Molecular epidemiology of rotaviruses in the south-east Asian region from 2009 to 2015. Vaccine. 2018.

9. Parashar UD, Gibson CJ, Bresee JS, Glass RI. Rotavirus and severe childhood diarrhea. Emerg Infect Dis. 2006;12(2):304.

10. DoHS: Annual Report 2073/74 (2016/17). In.: Minstry of Health and Population( MoHP), Department of Health service (DoHS) 2018. 
11. CDC: Rotavirus; Epidemiology and Prevention of Vaccine-Preventable Diseases, CDC, 2012; CDC 24/7: Saving Lives, Protecting People, http:// www.cdc.gov/.

12. Nguyen TV, Le Van P, Le Huy C, Weintraub A. Diarrhea caused by rotavirus in children less than 5 years of age in Hanoi, Vietnam. J Clin Microbiol. 2004; 42(12):5745-50.

13. Uchida R, Pandey BD, Sherchand JB, Ahmed K, Yokoo M, Nakagomi T, Cuevas LE, Cunliffe NA, Hart CA, Nakagomi O. Molecular epidemiology of rotavirus diarrhea among children and adults in Nepal: detection of G12 strains with P [6] or P [8] and a G11P [25] strain. J Clin Microbiol. 2006; 44(10):3499-505.

14. Sherchand JB, Nakagomi O, Dove W, Nakagomi T, Yokoo M, Pandey BD, Cuevas LE, Hart CA, Cunliffe NA. Molecular epidemiology of rotavirus diarrhea among children aged< 5 years in Nepal: predominance of emergent G12 strains during 2 years. The Journal of infectious diseases 2009. 200(Supplement_1):S182-7.

15. Gouvea V, Glass RI, Woods P, Taniguchi K, Clark HF, Forrester B, Fang Z. Polymerase chain reaction amplification and typing of rotavirus nucleic acid from stool specimens. J Clin Microbiol. 1990;28(2):276-82.

16. Sherchand J, Tandukar S, Sherchan J, Dhakwa J, Bichha R, Mahaseth C. Molecular epidemiology of Rotavirus diarrhea among children in Nepal: Emergence of G12 and G9 strains. Journal of Institute of Medicine. 2013;36:(1).

17. Dhital S, Sherchand JB, Pokhrel BM, Parajuli K, Shah N, Mishra SK, Sharma S, Kattel HP, Khadka S, Khatiwada S. Molecular epidemiology of rotavirus causing diarrhea among children less than five years of age visiting national level children hospitals, Nepal. BMC Pediatr. 2017;17(1):101.

18. Ansari S, Sherchand JB, Rijal BP, Parajuli K, Mishra SK, Dahal RK, Shrestha S, Tandukar S, Chaudhary R, Kattel HP. Characterization of rotavirus causing acute diarrhoea in children in Kathmandu, Nepal, showing the dominance of serotype G12. J Med Microbiol. 2013;62(1):114-20.

19. Pun S, Pandey B. Human rotavirus associated diarrhea and strain diversity in Nepal. Nepal Med Coll J. 2012;14(2):88-92

20. Saeed A, Abd H, Sandstrom G. Microbial aetiology of acute diarrhoea in children under five years of age in Khartoum, Sudan. J Med Microbiol. 2015; 64(4):432-7.

21. Akran V, Peenze I, Akoua-Koffi C, Kette H, De Beer M, Dosso M, Steele A. Molecular characterization and genotyping of human rotavirus strains in Abidjan, Cote d'Ivoire. Journal of Infectious Diseases. 2010;202(Supplement_ 1):S220-4

22. Reither $K$, Ignatius $R$, Weitzel T, Seidu-Korkor A, Anyidoho L, Saad E, DijeMaletz A, Ziniel P, Amoo-Sakyi F, Danikuu F. Acute childhood diarrhoea in northern Ghana: epidemiological, clinical and microbiological characteristics. BMC Infect Dis. 2007;7(1):104.

23. Sherchand J, Tandukar S, Sherchan J, Rayamajhi A, Gurung B, Shrestha L, Rijal B, Pokhrel B. Hospital-based study in children with rotavirus gastroenteritis and other enteropathogens. J Nepal Health Res Counc. 2012; 10(21):130-5.

24. Mwenda JM, Ntoto KM, Abebe A, Enweronu-Laryea C, Amina I, Mchomvu J, Kisakye A, Mpabalwani EM, Pazvakavambwa I, Armah GE. Burden and epidemiology of rotavirus diarrhea in selected African countries: preliminary results from the African Rotavirus Surveillance Network. Journal of Infectious Diseases. 2010;202(Supplement_1):S5-S11.

25. Shariff M, Deb M, Singh R. A study of diarrhoea among children in eastern Nepal with special reference to rotavirus. Indian J Med Microbiol. 2003;21(2):87.

26. Ahmed S, Kabir A, Rahman A, Hussain M, Khatoon S, Hannan A. Severity of rotavirus diarrhea in children: one year experience in a children hospital of Bangladesh. Iran J Pediatr. 2009;19(2):108-16.

27. Johargy A, Ghazi H, Mumenah A. Frequency of viral, bacterial and parasitic enteropathogens among young children with acute diarrhoea in Saudi Arabia. J Pak Med Assoc. 2010;60(6):456-9.

28. Shrestha S, Upadhyay B, Limbu B, Pradhan R, Nakagomi T, Thorson S, Pollard AJ, Adhikari N. Rotavirus and its genotype distribution among children less than three years presenting with acute watery Diarrhoea to a general Hospital in Urban Nepal. Journal of Nepal Paediatric Society. 2011;31(2):110-5.

29. Santos N, Hoshino Y. Global distribution of rotavirus serotypes/genotypes and its implication for the development and implementation of an effective rotavirus vaccine. Rev Med Virol. 2005;15(1):29-56.

30. Kargar M, Zare M, Najafi A. Molecular epidemiology of rotavirus strains circulating among children with gastroenteritis in Iran. Iran J Pediatr. 2012; 22(1):63.

\section{Ready to submit your research? Choose BMC and benefit from}

- fast, convenient online submission

- thorough peer review by experienced researchers in your field

- rapid publication on acceptance

- support for research data, including large and complex data types

- gold Open Access which fosters wider collaboration and increased citations

- maximum visibility for your research: over $100 \mathrm{M}$ website views per year

At $\mathrm{BMC}$, research is always in progress.

Learn more biomedcentral.com/submissions 